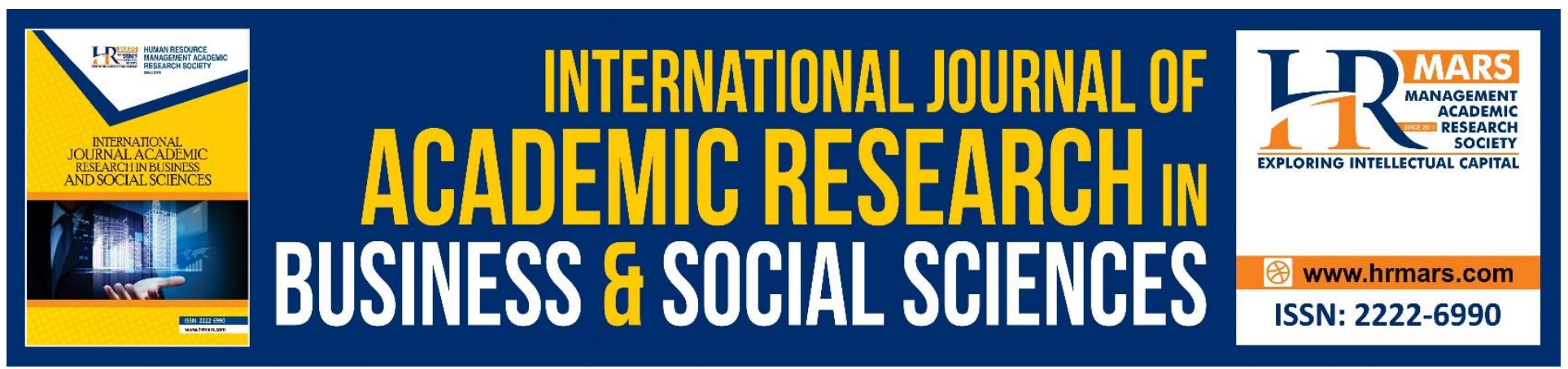

\title{
The Impact of Organizational Intelligence on Organizational Agility: An Empirical study in Syrian Private Banks
}

\author{
Hassan Ismail, Nour Al-Assa'ad
}

To Link this Article: http://dx.doi.org/10.6007/IJARBSS/v10-i2/6944

DOI:10.6007/IJARBSS/v10-i2/6944

Received: 23 January 2020, Revised: 02 February 2020, Accepted: 12 February 2020

Published Online: 22 February 2020

In-Text Citation: (Ismail \& Al-Assa'ad, 2020)

To Cite this Article: Ismail, H., \& Al-Assa'ad, N. (2020). The Impact of Organizational Intelligence on Organizational Agility: An empirical study in Syrian private Banks. International Journal of Academic Research in Business and Social Sciences, 10(2), 465-483.

\section{Copyright: (C) 2020 The Author(s)}

Published by Human Resource Management Academic Research Society (www.hrmars.com)

This article is published under the Creative Commons Attribution (CC BY 4.0) license. Anyone may reproduce, distribute, translate and create derivative works of this article (for both commercial and non-commercial purposes), subject to full attribution to the original publication and authors. The full terms of this license may be seen at: http://creativecommons.org/licences/by/4.0/legalcode

Vol. 10, No. 2, 2020, Pg. 465 - 483

Full Terms \& Conditions of access and use can be found at http://hrmars.com/index.php/pages/detail/publication-ethics 


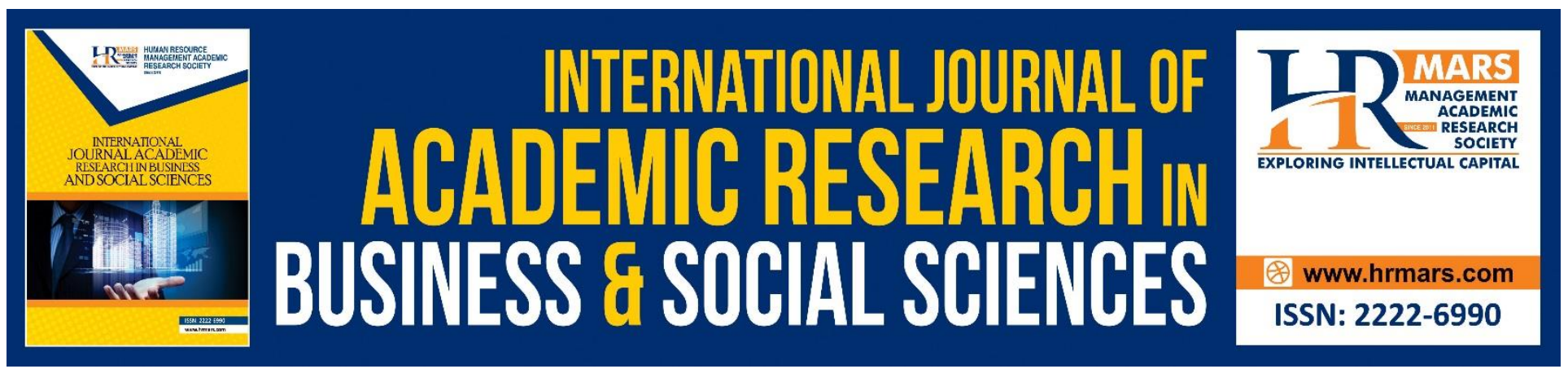

\title{
The Impact of Organizational Intelligence on Organizational Agility: An empirical Study in SYRIAN Private Banks
}

\author{
Hassan Ismail, Nour Al-Assa'ad \\ Researcher, Department of Human Resources management, Higher Institute of Business \\ Administration (HIBA), Damascus, Syria \\ Email: Hassanisml@gmail.com, Nour.damaso993@gmail.com
}

\begin{abstract}
This research aims to test the effect of organizational intelligence on organizational agility, which was applied on workers at top and middle management levels in Syrian private banks from Damascus city, A total sample of 160 employees was selected.

In order to achieve the objective of the research, a descriptive analytical approach was adopted. Secondary data were collected from previous studies and related references, while the questionnaire was the main research tool for collecting primary data.

To identify the dimensions of organizational intelligence, the study utilized the scale of (Albrecht, 2002), and in order to measure organizational agility, the researcher used the scale of (park, 2011).

After testing the research hypothesis, the main results of the research are:

There is a significant effect of one dimension of organizational intelligence (strategic vision) on Sensing Agility, There is a significant effect of organizational intelligence dimensions (Appetite for Change - strategic vision - Alignment and Congruence) on Decision-making Agility, There is a significant effect of organizational intelligence dimensions (Appetite for Change - strategic vision alignment and Congruence) on Decision-making Agility.

Keywords: Organizational Intelligence, Organizational Agility, Strategic Vision, Shared Fate, Appetite for Change, Heart, Alignment and Congruence, Knowledge development \& performance pressure, Sensing Agility, Decision-making Agility, Acting Agility/Practicing
\end{abstract}

\section{Introduction}

In the present era, institutes, organizations, departments with any missions, aim or prospect act at a national or international level and they have to respond to the needs of the customers and those who benefit from their service. Therefore, studying the results of their functioning will be considered an important strategic process. The recent study in the area of human resources indicated that the five attributes of personality, predisposition, interest, intelligence, and skill are very effective and important for the improvement of organizational goal, job satisfaction, organizational learning, the 
tendency for knowledge and the creativity coefficient and assessment of the staff. And, these attributes are very important for the success of the human resources. Today we can claim with one hundred percent of confidence that the identification and the use of organizational intelligence can improve the compatibility of an organization and can make it distinct from other organizations.

The necessity to study organizational intelligence at the present time is actually response to the present needs of the managers (Daraei, Ahmadi and Faraji, 2015). In addition, the increasing speed of the changes in the modern technology in one hand, and the changes of the identity of customer's demands and also the increasing competition between organizations on the other hand caused the organizations to follow new competitive advantages in order to be superior to their rival and answer the needs of their customers better. Regarding this problem, it seems that moving towards creating an organization which is highly flexible in response to the changing, unstable and unpredictable condition and environment, is a new and vital solution. Achieving this goal is only possible under the umbrella of a new concept called organizational agility.

Therefore, the value and importance of organizational agility is that it equals the speed and quickness of responsiveness and organizational flexibility against changes (Adel \& Pishdar, 2011)

Today, the agility is considered as dominant paradigm in the third millennium and as the best option for survival of organizations which is considered by the general manufacturing and service organizations.

Today, the agility is considered as dominant paradigm in the third millennium and as the best option for survival of organizations which is considered by the general manufacturing and service organizations.

Following this consideration, some efforts have run to achieve the desired level of organizational agility. Agility only is achieved by hierarchical integration of customers in the context of the organization's internal and external environment. This is done by having a comprehensive view towards advanced technology in manufacturing organizations with their internal capabilities and also using the information technology (Ramesh and Devadasan, 2009).

In fact, organizational agility can easily cause significant change in the focus, diversification and renovation of business for accelerating the achievement of a specific goal; in a way that can create valuable opportunities for the organization. These organizations can precede in the competition and the key to this issue is strategic planning which represents a wide map of abilities, capabilities and main skills of the organization; Therefore, each section determines the policies for increasing the organizational agility based on its specific strategies.

Agile organization combines the processes and people with the advanced technology and the needs of the customers to present services with high quality is quite short time. Agility constantly pays attention to the performance of the personnel and the organization, value of the products and services and opportunities for attracting customers and requires permanent preparedness to confront the fundamental and surface changes and agile organizations are always ready to learn new things in order to increase profitability resulting from new opportunities.

Agility creates an essential ability in order for the organization to sense, receive, observe, analyze and predict the changes in the environment. Therefore, an organization is agile if it has a wide view about the new global order and confronts the turmoils with its abilities and competencies and seize the advantage aspects of trends.

The purpose of the current research is to: 1) study the Impact of Organizational Intelligence on Organizational Agility, 2) provide solutions for improving organizational agility based on 
INTERNATIONAL JOURNAL OF ACADEMIC RESEARCH IN BUSINESS AND SOCIAL SCIENCES

Vol. 10, No. 2, Feb, 2020, E-ISSN: 2222-6990 @ 2020 HRMARS

organizational intelligence.

\section{Literature Review and Hypothesis Development}

The initial idea of organizational intelligence (OI) has been addressed by most of the researchers over the past few decades in various research disciplines (Albrecht, 2003; Travica, 2014; Wassermann, 2001; (Cronin \& Davenport, 1991); Argyris \& Schön, 1978; Wilensky, 1967).

Few researchers argued that an intelligent organization have the capacity to take right decisions (March, 1999; Quinn 1992; Wilensky, 1967) while others feels that it is up to the organization that how to fit in environment for its survival and growth (Thannhuber, 2005; Gupta \& Sharma, 2004).

The early concept of OI came into academic setting in 1980s. However, later on, some authors believe that it was the Michel Porter who first introduced the concepts of organizational intelligence and competitive intelligence. On the other hand, it is firmly believed that (Karl Albrecht, 2003) has been considered as the pioneers in introducing the concept and real model of Ol. He has argued that human resources are one of the very intelligent and competent in performing all the organizational tasks but on the other hand he has highlighted the competitive abilities of a collective mental power in doing great jobs (Bakhshian, Hamidi, \& Ezati, ,2011).

Organizational intelligence: having a deep knowledge about all factors like customers (the society and addresses, clients, etc), competitors, economic environment, operation and organizational processes (financial, sale, production, human resources, etc) which have a great effect on management decision makings in the organization is organizational intelligence. Organizational intelligence enables you for decision making in all factors effective on the organization and companies (Chaman, Hesam \& Yazdanpanah, 2016) Organizational intelligence includes an organization talent and capacity for rousing the organization mental ability and concentrating this ability for reaching the organizational prophecy.

Experts have provided different definitions of organizational intelligence:

1. Glynn argues that organizational intelligence is the result of addition and interaction of the intelligences of the individuals in an organization. Organizational intelligence is a social process whose theory is designed based on human intelligence theories (Glynn, 1996).

2. McMaster (1996) defined organizational intelligence as the capacity of a system to accumulate information, innovation, production of knowledge and deploying that knowledge in the organization (McMaster,1996).

3. According to Liebowitz, organizational intelligence can be defined as a horde of all intelligences which are employed in order to create a common outlook, to conduct revision process and to direct the whole system (Liebowitz, 1999).

4. In Simic's opinion, organizational intelligence is intellectual ability of an organization to solve organizational problems and its emphasis is on the concentration of human and technical abilities in problem-solving (Simic, 2005).

5. Matsuda contends that organizational intelligence is a complex, interactive, accumulated, coordinating set of the organization's human and machine intelligences as a whole (Matsuda, 1988).

6. Karl Albrecht defines organizational intelligence as the ability that provokes intellectual capacities of an organization and concentrates them to reach the missions (Albrecht, 2003). 
INTERNATIONAL JOURNAL OF ACADEMIC RESEARCH IN BUSINESS AND SOCIAL SCIENCES

Vol. 10, No. 2, Feb, 2020, E-ISSN: 2222-6990 @ 2020 HRMARS

7. In Halal's idea, organizational intelligence is creating and deploying the proper knowledge in adaptation to the environment (Halal, 2000).

8.(Kord, Ghasemi \& Amin, 2013) considers organizational intelligence the ability of an organization in comprehending and responding to the environment in order to achieve its goals and satisfies its stakeholders (Kord, Ghasemi and Amin, 2013).

9. Leon and Gabriela maintain that organizational intelligence is the ability of an organization in creating knowledge and deploying it strategically so as to adapt to its environment (Leon, Florin, Gabriela \& Atanasiu, 2009).

\section{Components of Organizational Intelligence}

According to (Albrecht, 2003), he coined the concept of organizational intelligence into seven dimensions. Each of the seven dimensions of organizational intelligence contains a set of behaviors, structural characteristics, processes or specific way they function. Each of these characteristics has their own causes or history.

Records may include organizational structures, competitive leadership, products and processes to suit the needs of the business environment, interrelated missions, clear goals, core values and policies which define the rights and functions of the staff as well. In each of these dimensions can be identified multiple records to increase the elements of organizational intelligence in their maximum level. The seven dimensions are including as below (Sattari, 2007).

- Strategic Vision: Every organization in a sense needs an organized principle and a definition of the destination it is attempting to reach. The leaders of organizations have to have answers to these questions: Who are we? What do we exist for? What is the philosophy of our existence? Why should our fellow countrymen and even the people of the world accept us, appreciate us and pay us for what we do? Notice that strategic vision refers to organizational ability in creating, nourishing, and expressing the aims of the organization. The assumption of the strategic vision is that the leaders are able to express the concept of success and when needed they are able to recreate this concept (Albrecht, 2003).

- Shared Fate: This means that the staffs are able to cooperatively step towards their visions and reach a feeling of "being on the same boat." This gives them a sense of unity and oneness. Alternatively, when members and employees lack a common outlook and concept of success, there is no hope for that boat to reach its destination (Albrecht, 2003).

- Appetite for Change: In some organizational cultures, the way of functioning, thinking, and reacting to the surrounding environment is stabilized to the extent that any change is a considered an illness or a riot. On the other hand, in some others, the word "change" refers to gaining new experiences and it is an exciting term, and in other words it is "a chance to start a new activity." People in this second kind need the recreation of models of business as an exciting challenge and see the change as an opportunity to learn new methods. This parameter is the driving force for the strategic vision (Albrecht, 2003).

- Heart: This dimension is the willingness to cooperate over the standard. Each and every member of the staff has to be responsible to cooperate in the affairs of the organization. The amount of energy over your regular responsibility is call optional attempt by social psychologists. In organizations with little or no emotional bonds, staffs only do what they have to. In organizations with high rate of love of work, members will cooperate more than what they are expected to (Albrecht, 2003). 
- Alignment and Congruence: Any group of over 12 people will clash without a determined system of rules. They have to organize, divide responsibilities, and set rules for interaction and response to environment. In short, in intelligent organizations, organizational system and structure and rules and regulations are in the direction of group learning and cooperation of the employees and eventually, creation of values and getting the mission done (Albrecht, 2003).

- Knowledge Deployment: Today, more than ever, success and failure of organizations are based on their effective use of data, information and knowledge. Capacity of creation, transference, organization, sharing and deploying knowledge is a vital and significant aspect of competition in complicated environments. The factor "knowledge deployment" shows the capacity that the culture and atmosphere create to use valuable mental and information resources (Albrecht, 2003).

In this regard, knowledge deployment is better to be considered a humanistic factor than a structural or technological one. Organizational intelligence includes free flow of knowledge all over the organization and making a balance between maintaining invaluable information and access of key people to it when it is due. Encouraging and protecting new ideas and questioning the current conditions are other features of this facet of organizational intelligence (Albrecht, 2003).

- Performance Pressure: This is not correct that only managers get involved with the performance and in other words, reaching the strategic goals and results. In an intelligent organization, each person is responsible about their own performance. When each person is asked questions about their share of responsibility the culture of performance pressure is shaped and any new member can feel this common sense (Albrecht, 2003).

Having said all this, one can conclude that organizational intelligence of the experts is very crucial for any organization.

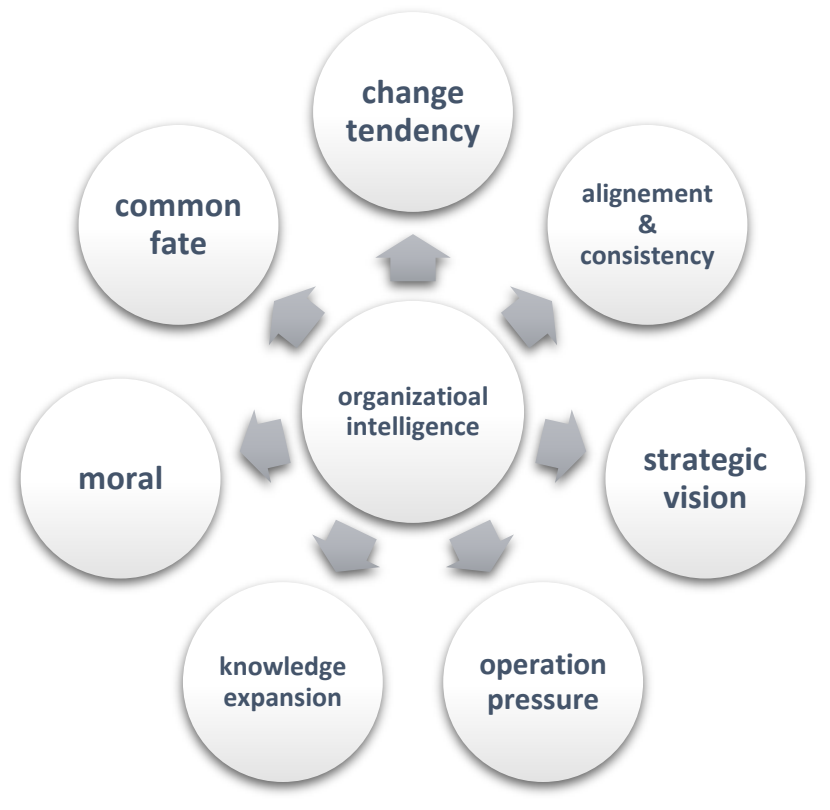

Figure 1: Albrecht organizational intelligence model, 2003 
INTERNATIONAL JOURNAL OF ACADEMIC RESEARCH IN BUSINESS AND SOCIAL SCIENCES Vol. 10, No. 2, Feb, 2020, E-ISSN: 2222-6990 @ 2020 HRMARS

\section{Organizational Agility}

The concept of agility needs to be well grounded in management theory (Yusuf et al., 1999). Early in the 1990s, the new solution for managing a dynamic and changing environment emerged; agility. Agile manufacturing is the ability of surviving and prospering in a competitive environment of continuous and unpredictable change by reacting quickly and effectively to changing markets, driven by customer-defined products and services (Gunasekaran, 1999).

The creators of "agility" concept at the lacocca Institute, of Lehigh University (USA) defined it as a manufacturing system with capabilities (hard and soft technologies, human resources, educated management, information) to meet the rapidly changing needs of the marketplace (speed, flexibility, customers, competitors, suppliers, infrastructure, responsiveness). Agility is the successful application of competitive bases such as speed, flexibility, innovation, and quality by the means of the integration of reconfigurable resources and best practices of knowledge-rich environment to provide customer-driven products and services in a fast-changing environment (Yusuf et al., 1999). The notion of organizational agility has its origins in flexible manufacturing systems, where it was believed that automation alone would confer this capability. Agility is ability to respond to unpredictable changes with quick response and profitability (Erande and Verma, 2008). When thinking about agility, it is important to pay attention to the whole system and simultaneously improve the nimbleness of direction, focus, speed, quality, and sustainability. According to the different definitions of the word agility, the concept of speed and quick response and also the concepts of group work and common goal regarding the word organization can be inferred from. Also, we can propose a primary definition for the word organizational agility as follows: "Swiftness and quick response of a harmonious group to the changes made by the environment surrounding them in order to reach a goal." But agility has some components that are introduced in the following. Two concepts inherent to the definition of agility are speed and flexibility (Prater, BiehI\& Smith, 2001).

Agility is an ability to respond and react quickly and successfully to the environmental changes. An agile organization will not lose its uniformity easily by sudden change of events. An agile organization is high-speed, consistent, and powerful and therefore gives rapid response to sudden changes, new market opportunities, and customer requirements. An agile organization can understand and predict the changes in the business environment to make its structure properly (McCarthy, 2010)).

$\mathrm{OA}$ is the successful application of the competition rules, such as speed, flexibility, innovation and quality, through the means of integration of resources and the restructuring of best practices in the environment of technical knowledge, through the provision of services or products that meet customers' preferences in light of a rapidly changing environment (Yusuf et al., 1999).

OA quickly meets customer requests, offers new products, and gets on strategic alliances or gets rid of them. This means that organizations are in an urgent need of strategic alliances in order to solve the problems of its customers, rather than providing products or one service. The fundamental reason behind the necessity of $O A$ is searching for the core capabilities, on the one hand, and identifying the business environment and capturing opportunities, on the other hand (McCarthy., 2010).

$\mathrm{OA}$ is the manufacturing system for physical and non-physical technology, human resources, educated management and information in order to meet the rapidly changing needs of the market in a manner that achieves the desires and needs of the customers in time (Park, 2011). 
In light of this, the researcher does identify OA as the organization's ability to achieve its objectives, through the development of its products increasing knowledge of its human resources, effecting the development of the organization and lightening its movement in a rapidly changing environment.

On the other hand, (Harraf, Wanasika, Tate and Talbott, 2015) in his article regarded the use of business knowledge and the opportunity provided by virtual organization and organizational agility. According to (Van Hook et al ,2001), organizational agility is obtained through getting the necessary abilities by use of thoughts and responding to the customer's needs.

(Aitken et al 2002) regarded the ability of distinguishing the need, quick response, flexibility, and simultaneous production as the attributes of organizational agility. (Park, 2011) in his research pointed out that the existence of the demand of variable and consequently innovative production and product are considered the main factor for creating agility in organization. (Janssen,2010) in his research defined organizational agility as the flexibility of a sensitive institution in order to respond quickly to the planned and unplanned changes. Of course, he further added that this job is carried out in a short-term period., economical high quality and simple devices are used in a dynamic environment and also, he updates his previous knowledge and experiences in order to learn from external and internal environment (Blue,2011).

McCann, (Selsky, and Lee, 2009) emphasized the important of a systemic approach to building organizational agility:

- "We are struck by how the agility and resilience literatures focus on individuals, team, and organizations, but rarely two or more of these at the same time. Emphasizing agility-building interventions such as systems thinking or creative problem-solving workshops at an individual or team level may be helpful, but if efforts to build agility across the organization are weak, then individual and team level efforts ultimately fail." (McCann, 2009)

The dimensions of the OA are three main types. They are sensing agility, decision-making agility and acting agility (Park, 2011).

\section{Sensing Agility}

Sensing agility is the organizational capacity to inspect and monitor events and changes in the surrounding environment (customer preferences changes, the movements of the new competitors, new technology) in a timely manner (Park, 2011). The task of sensing means the strategic monitoring of environmental events that could have an impact on organizational strategy, competitive work, and future performance, including several activities such as

access to information related to the events which show environmental change, on the one hand, and getting rid of the trivial information, on the other hand, in light of predetermined foundations and rules (El-Sawy, 1985). This task is related to decision-making and its execution (Daft \& Weick, 1984; Dutton \& Duncan, 1987). It is interested in organizational adaptation to change in the surrounding environment (Smircich \& Stubbart, 1985).

\section{Decision-Making Agility}

Decision-making agility process is the ability to collect, accumulate, restructure and evaluate relevant information according to a variety of sources to explain the implications of the business without delay, and to identify opportunities and threats based on the interpretation of events, along with the development of action plans, which direct the reconfiguration of resources and the development of 
INTERNATIONAL JOURNAL OF ACADEMIC RESEARCH IN BUSINESS AND SOCIAL SCIENCES Vol. 10, No. 2, Feb, 2020, E-ISSN: 2222-6990 @ 2020 HRMARS

new competitive procedures (Park, 2011). The decision-making task consists of several interrelated activities, which explain many events and identify opportunities and threats in the surrounding environment. Decision-making task focuses on collecting information from multiple and diverse sources in order to understand the implications of their work (Thomas et al, 1993). Decision-making task seeks to capture the utmost opportunities and minimize the impact of threats on the life of the organization (Houghton et al., 2004).

Acting Agility/Practicing

The acting task consists of a set of activities for re-assembling organizational resources and modifying business processes on the basis of the principles of work resulting from the task of decision-making in order to address the change that occurs in the surrounding environment (Eisenhardt \& Martin, 2000). Organizations can change the business processes by various procedures and resources, redesigning the organizational structure of the organization (Dutton \& Duncan, 1987; Thomas et al., 1993).

\section{Previous Studies}

(Ameri, 2009) studied the relationship between organizational intelligence and organization agility. The results showed that there was a significant positive relationship between organizational agility and its components in terms of demographic characteristics expect for field studies. Moreover, there were a significant positive relationship between intelligence and its components and organizational agility in administration. The results of his study showed that there was a significant difference between line and staff units regarding to organizational intelligence. Furthermore, there was a significant difference between line and staff units of Sepah Bank in terms of strategic vision, belief in common destiny, the index of unity and consensus, morale, assessing the knowledge and attitude of managers in relation to the employees' performance. It also indicated that there was a significant difference in both line and staff units based on the desire of the personnel changes.

(Bagherzadeh and Debar, 2010) investigated the relationship between organizational intelligence and organizational agility. The results of his study showed that there was a significant positive correlation between organizational intelligence and organizational agility. Also, there were significant relationships between some dimensions of intelligence including common fate, desire for change, unity and consensus, morale, knowledge application, and performance pressure with organizational agility but he could not find any significant relationship between organizational agility and strategic vision (Khodadadi, Kashef, Ameri \& Kashki, 2013).

(Lefter, Prejmerean, and Vasilache, 2008) studied the organizational intelligence of Romanian companies in which human was the main capital. The results showed that only 13 percent of employees in small firms did not recognize this concept. However, the results of data analysis showed that organizational intelligence was in the average or high level. Then, the components of intelligence were identified based on Albrecht's view (2002, 2003).

(Chakir and Ada, 2008) investigated the role of training at the workplaces to develop organizational intelligence in Turkey. The results tended to differ substantially in intelligence before and after the workshop. There was not a significant difference in the efficiency of communication among colleagues.

\section{Hypothesis}

In line with the discussion above, the following research hypotheses were formulated: 
INTERNATIONAL JOURNAL OF ACADEMIC RESEARCH IN BUSINESS AND SOCIAL SCIENCES Vol. 10, No. 2, Feb, 2020, E-ISSN: 2222-6990 @ 2020 HRMARS

H1: There is a significant effect of organizational intelligence on organizational agility. The following sub-hypotheses are derived:

- H1-1: There is a significant effect of organizational intelligence on Sensing Agility.

- H2-1: There is a significant effect of organizational intelligence on Decision-Making Agility

- H3-1: There is a significant effect of organizational intelligence on agility in behavior or practice.

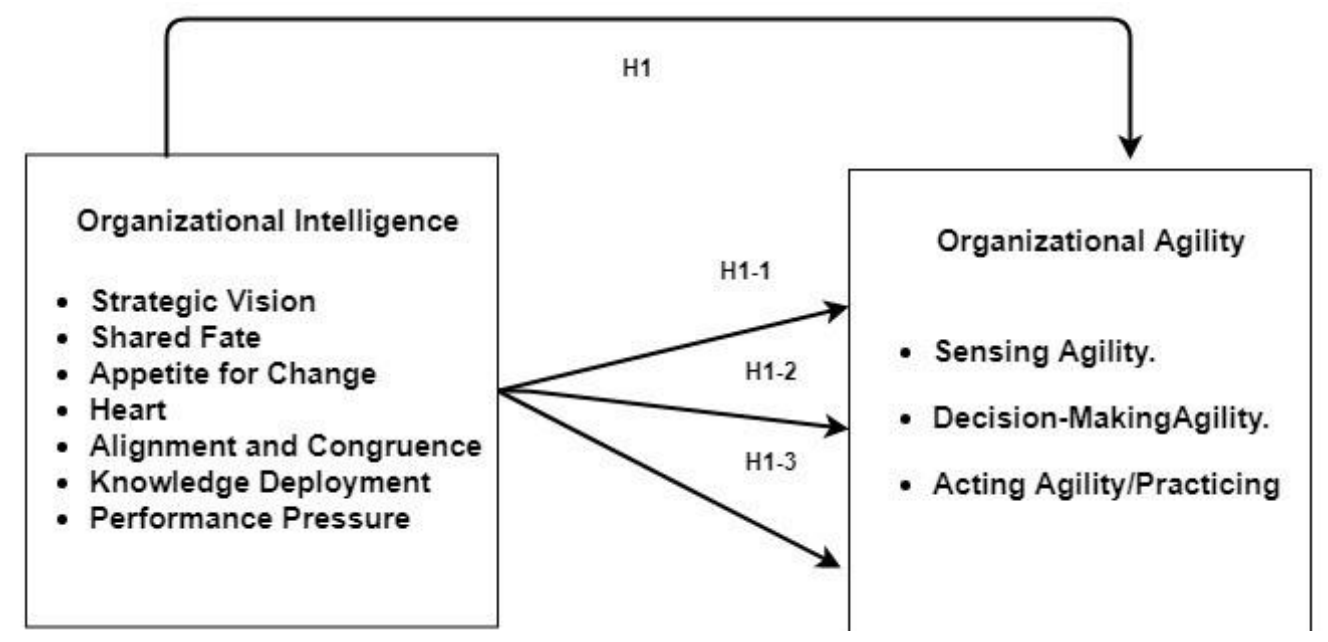

\section{Research Methodology}

\section{Data Collection and Sample}

Data for this study were collected from both primary and secondary sources. Secondary data were collected through comprehensive literature review. The primary data were collected from Top \& Middle management Levels from Syrian private banks. A total sample of 160 respondents was selected. A questionnaire related to the study's variables was the main tool of this study.

\section{Measurement}

The questionnaire included three sections: organizational intelligence (Strategic Vision, Shared Fate, Appetite for Change, Heart, Alignment \& Congruence, Knowledge Deployment and Performance Pressure), organizational agility (Sensing Agility, Decision-Making Agility and Acting Agility/Practicing) and basic demographic information. Apart from basic demographic information, a 5-point Likert scale format was used, and the scores on the scale ranged from 1=Strongly Disagree to 5= Strongly Agree. 4.1 organizational intelligence: organizational intelligence is measured using 46 items, 5 items for each dimension which is taken from study by (Albrecht, 2002), the scale reported reliability $0.85 \%$. 4.2 organizational agility: organizational agility is measured using 13 items which is taken from study by (park, 2011). The scale reported reliability $0.82 \%$.

\section{Data Analysis}

H1-1: There is a significant effect of organizational intelligence on Sensing Agility. This study examines the impact of organizational intelligence on organizational agility. 
INTERNATIONAL JOURNAL OF ACADEMIC RESEARCH IN BUSINESS AND SOCIAL SCIENCES Vol. 10, No. 2, Feb, 2020, E-ISSN: 2222-6990 @ 2020 HRMARS

Table (1) shows the results of regression analysis regarding the impact of organizational intelligence (strategic vision) on the dependent variable: organizational agility (sensing agility). As presented in this table, model is significant at the $5 \%$ level $(\mathrm{R} 2=.521)$.

Table (1)

Model Summary

\begin{tabular}{lr|r|r|r|r} 
Model & R & R Square & Adjusted R Square & $\begin{array}{c}\text { Std. Error of the } \\
\text { Estimate }\end{array}$ & Durbin-Watson \\
\hline 1 & $.722^{\mathrm{a}}$ & .521 & .408 & .59302 & 1.768 \\
\hline
\end{tabular}

a. Predictors: (Constant), strategic vision

b. Dependent Variable: sensing agility

Table (2) shows the results of regression analysis regarding the impact of organizational intelligence (appetite for change, strategic vision, Alignment \& Congruence) on dependent variable: organizational agility (decision - making agility). As presented in this table, model is significant at the $5 \%$ level $(\mathrm{R} 2=.523, .540, .571)$.

Table (2)

Model Summary ${ }^{d}$

\begin{tabular}{lr|r|r|r|r} 
Model & R & R Square & Adjusted R Square & $\begin{array}{r}\text { Std. Error of the } \\
\text { Estimate }\end{array}$ & Durbin-Watson \\
\hline 1 & $.725^{\mathrm{a}}$ & .523 & .434 & .59272 & \\
\hline 2 & $.735^{\mathrm{b}}$ & .540 & .476 & .57068 & \\
\hline 3 & $.756^{\mathrm{c}}$ & .571 & .490 & .56315 & 2.096 \\
\hline
\end{tabular}

a. Predictors: (Constant), appetite for change

b. Predictors: (Constant), appetite for change, strategic vision

c. Predictors: (Constant), appetite for change, strategic vision, Alignment \& Congruence

d. Dependent Variable: decision - making agility

Table (3) shows the results of regression analysis regarding the impact of organizational intelligence (appetite for change, strategic vision, Alignment \& Congruence) on dependent variable: organizational agility (acting (practicing) agility). As presented in this table, model is significant at the $5 \%$ level $(\mathrm{R} 2=.641, .727, .762)$.

Table (3) Model Summary ${ }^{d}$

\begin{tabular}{lr|r|r|r|r} 
Model & R & R Square & Adjusted R Square & $\begin{array}{r}\text { Std. Error of the } \\
\text { Estimate }\end{array}$ & Durbin-Watson \\
\hline 1 & $.801^{\mathrm{a}}$ & .641 & .572 & .47704 & \\
\hline 2 & $.853^{\mathrm{b}}$ & .727 & .640 & .43755 & \\
\hline 3 & $.873^{\mathrm{c}}$ & .762 & .655 & .42817 & 1.993 \\
\hline
\end{tabular}

a. Predictors: (Constant), appetite for change

b. Predictors: (Constant), appetite for change, strategic vision

c. Predictors: (Constant), appetite for change, strategic vision, Alignment \& Congruence 
INTERNATIONAL JOURNAL OF ACADEMIC RESEARCH IN BUSINESS AND SOCIAL SCIENCES Vol. 10, No. 2, Feb, 2020, E-ISSN: 2222-6990 @ 2020 HRMARS

\section{d. Dependent Variable: acting (practicing) agility}

Table (4) shows that we find that the previous statistical data invites us to accept the partially tested hypothesis:

It turns out that the strategic vision variable is the only dimension of organizational intelligence that has the significant impact on sensing agility at the multiphase regression model, and with a statistically significant regression coefficient at the significance level $(\alpha<0.05)$ it reached $(0.732)$. Accordingly, there is no significant impact on the rest dimensions of organizational intelligence (Shared Fate, Appetite for Change, Heart, Alignment \& Congruence, Knowledge Deployment and Performance Pressure) in sensing agility at the level of significance (0.05).

Table (4)

\section{Coefficients $^{a}$}

\begin{tabular}{lc|c|c|c|c|c|c|} 
& \multicolumn{2}{c}{$\begin{array}{c}\text { Unstandardized } \\
\text { Coefficients }\end{array}$} & $\begin{array}{c}\text { Standardized } \\
\text { Coefficients }\end{array}$ & & \multicolumn{2}{c}{$\begin{array}{c}\text { Collinearity } \\
\text { Statistics }\end{array}$} \\
Model & B & Std. Error & Beta & T & Sig. & Tolerance & VIF \\
\hline strategic vision & .732 & .069 & .652 & 10.526 & .000 & 1.000 & 1.000 \\
\hline
\end{tabular}

a. Dependent Variable: sensing agility

Table (5) shows that we find that the previous statistical data invites us to accept the partially tested hypothesis:

It turns out that the appetite-for-change variable was the first level and explained measure of which is (43.4\%) From the varying of decision - making agility and a statistically significant regression coefficient at the significance level $(\alpha<0.05)$ where it reached $(0.341)$ and represents the strength of its effect in the regression model.

Then the impact of the strategic vision variable became at the second level in order to explained with appetite for change measure of which is (47.6\%) From the variation in decision - making agility and a statistically significant regression coefficient at significance level $(\alpha<0.05)$ where it reached $(0.289)$ and represents the strength of its effect in the regression model.

Then the impact of the Alignment \& Congruence variable became at the third level in order to explained measure of which is (49\%) From the variation in decision - making agility and a statistically significant regression coefficient at significance level $(\alpha<0.05)$ where it reached $(0.238)$ and represents the strength of its effect in the regression model.

Accordingly, there is no significant impact on the rest dimensions of organizational intelligence (Shared Fate, Heart, Knowledge Deployment and Performance Pressure) in sensing agility at the level of significance (0.05). 
INTERNATIONAL JOURNAL OF ACADEMIC RESEARCH IN BUSINESS AND SOCIAL SCIENCES Vol. 10, No. 2, Feb, 2020, E-ISSN: 2222-6990 @ 2020 HRMARS

Table (5)

Coefficients $^{\text {a }}$

\begin{tabular}{|c|c|c|c|c|c|c|c|}
\hline \multirow[b]{2}{*}{ Model } & \multicolumn{2}{|c|}{$\begin{array}{l}\text { Unstandardized } \\
\text { Coefficients }\end{array}$} & \multirow{2}{*}{$\begin{array}{c}\text { Standardized } \\
\text { Coefficients } \\
\text { Beta }\end{array}$} & \multirow[b]{2}{*}{$\mathrm{t}$} & \multirow[b]{2}{*}{ Sig. } & \multicolumn{2}{|c|}{$\begin{array}{l}\text { Collinearity } \\
\text { Statistics }\end{array}$} \\
\hline & B & $\begin{array}{l}\text { Std. } \\
\text { Error }\end{array}$ & & & & Tolerance & VIF \\
\hline appetite for change & .341 & .101 & .325 & 3.388 & .001 & .349 & 2.866 \\
\hline strategic vision & .289 & .097 & .263 & 2.987 & .003 & .415 & 2.409 \\
\hline $\begin{array}{l}\text { Alignment \& } \\
\text { Congruence }\end{array}$ & .238 & .104 & .195 & 2.285 & .024 & .441 & 2.266 \\
\hline
\end{tabular}

a. Dependent Variable: decision - making agility

Table (6) shows that we find that the previous statistical data invites us to accept the partially tested hypothesis:

It turns out that the appetite-for-change variable was the first level and explained measure of which is (57.2\%) From the varying of acting (practicing) agility and a statistically significant regression coefficient at the significance level $(\alpha<0.05)$ where it reached $(0.349)$ and represents the strength of its effect in the regression model.

Then the impact of the strategic vision variable became at the second level in order to explained with appetite for change measure of which is (64\%) From the variation of acting (practicing) agility and a statistically significant regression coefficient at significance level $(\alpha<0.05)$ where it reached (0.349) and represents the strength of its effect in the regression model.

Then the impact of the Alignment \& Congruence variable became at the third level in order to explained measure of which is (65.5\%) From the variation of acting (practicing) agility and a statistically significant regression coefficient at significance level $(\alpha<0.05)$ where it reached $(0.223)$ and represents the strength of its effect in the regression model.

Accordingly, there is no significant impact on the rest dimensions of organizational intelligence (Shared Fate, Heart, Knowledge Deployment and Performance Pressure) in sensing agility at the level of significance (0.05).

Table (6)

Coefficients $^{a}$

\begin{tabular}{|c|c|c|c|c|c|c|c|}
\hline \multirow[b]{2}{*}{ Model } & \multicolumn{2}{|c|}{$\begin{array}{c}\text { Unstandardized } \\
\text { Coefficients }\end{array}$} & \multirow{2}{*}{$\begin{array}{c}\text { Standardized } \\
\text { Coefficients } \\
\text { Beta }\end{array}$} & \multirow[b]{2}{*}{$t$} & \multirow[b]{2}{*}{ Sig. } & \multicolumn{2}{|c|}{ Collinearity Statistics } \\
\hline & B & $\begin{array}{l}\text { Std. } \\
\text { Error }\end{array}$ & & & & Tolerance & VIF \\
\hline $\begin{array}{l}\text { appetite for } \\
\text { change }\end{array}$ & .349 & .076 & .360 & 4.561 & .000 & .349 & 2.866 \\
\hline strategic vision & .349 & .074 & .342 & 4.735 & .000 & .415 & 2.409 \\
\hline $\begin{array}{l}\text { Alignment \& } \\
\text { Congruence }\end{array}$ & .223 & .079 & .198 & 2.820 & .005 & .441 & 2.266 \\
\hline
\end{tabular}

a. Dependent Variable: acting (practicing) agility 
INTERNATIONAL JOURNAL OF ACADEMIC RESEARCH IN BUSINESS AND SOCIAL SCIENCES Vol. 10, No. 2, Feb, 2020, E-ISSN: 2222-6990 @ 2020 HRMARS

\section{Conclusion}

This article aimed to study The Impact of Organizational Intelligence on Organizational Agility. This study shows that strategic vision has significant impact on sensing agility $(B=0.37)$ at a level of significance (Sig <= 0.001), while (Shared Fate, Appetite for Change, Heart, Alignment \& Congruence, Knowledge Deployment and Performance Pressure) didn't show any significant impact on sensing agility, the researcher finds that if the organizations were more interested in strategic vision, "to determine the path adopted by the organization to achieve its mission under the surrounding environmental conditions and competition and the exploitation the highly experienced individuals and their insight into the future directions of the organization and its strategic objectives," therefore, Organizations reach into high levels of sensing agility in the company, ie increase their ability to keep up with changes in the regulatory environment of customer preferences, the movements of new competitors and modern technological means by responding well to changes in Taking action and generate new insights in the restructuring of organizational behavior, and this result are Compatible with previous literature e.g. This study is Partially compatible with study of (Sheikh, Mahmoudil, and Asgari, 2013) of high school principals in Mazandaran Province in Iran, and also It is not Compatible with the study of (Sohhrabi, Asari, and Hozoori, 2014) that applied to managers and employees of companies for information systems and development of operating systems and development that exclude the strategic vision because it is correlated to a positive relationship with organizational agility, This result shows that the managers of these companies do not have the high experience and insight into shaping the company's future directions and strategic pathways to achieve its goals, especially those of reaching high organizational agility.

This study shows that (appetite for change, strategic vision and Alignment \& Congruence) have significant impact on decision - making agility \& acting (practicing) agility at a level of significance (Sig $<=0.001$ ) while (Shared Fate, Heart, Knowledge Deployment and Performance Pressure) didn't show any significant impact on decision - making agility \& acting (practicing) agility, Commenting on the previous two hypotheses, the researcher finds that the greater the interest of organizations in the strategic vision and dialogue, that is, defining the path adopted by the organization to achieve its mission and goals in light of the surrounding environmental conditions and the desire to change in line with developments and opportunities with the external environment is accelerating to engage in new experiences and increase innovation and Moving away from the bureaucracy in its management, alignment and congruence by the leaders of organizations in controlling differences and solving them and harnessing the energies of human workers towards goals of value and interactivity, so organizations reach high levels of decision-making agility in Interpretation of polarized events to take actual business plans and initiate new competitive measures in the market in a timely manner, and also to reach to acting ( practicing ) agility in radically reshaping organizational resources and presenting new ideas in to labor market through competitive price models and actual plans on the one hand and from the other hand to redesigning their organizational structure and establishing policies with strategic partners and major customers in a timely manner.

Through focusing more on the results of this research, These two results are Partially compatible with the study of (Soodi, Rasouli and Jafarzadeh, 2016) at the University of Payame Noor in Sari, Iran, and also Partially compatible with the study of (Rahimia, and Mansouri, 2016) in the staff of the city of Tabriz in Iran, and It also partially agrees with the study of (Sohhrabi, Asari, and Hozoori, 2014) on managers and employees of companies in the systems of informatics and development of operating systems and development. 
INTERNATIONAL JOURNAL OF ACADEMIC RESEARCH IN BUSINESS AND SOCIAL SCIENCES Vol. 10, No. 2, Feb, 2020, E-ISSN: 2222-6990 @ 2020 HRMARS

\section{Theoretical and Contextual Contribution}

The researcher recommends corporate leaders to continue adopting organizational intelligence policies by having a clear vision, and a flexible organizational structure that supports renewal by permanently re-engineering organizational processes, and adopting a culture that encourages continuous learning to spread knowledge among employees through the latest modern means to enable employees to refer and amend them When needed and at any time, and also Building a comprehensive procedural system for administrative operations by eliminating bureaucracy and routine, as the reality of these sector is suffering from administrative slackness and stereotypes and fear of innovation and renewal and its adoption by applying fixed systems and regulations at the expense of work results and their effectiveness, in addition to the method of communication between superiors and subordinates away from Development, renewal and atypical solutions. Managers should increase the quality of the work style for all employees, where this quality rises when individuals have jobs that provide them with independence and a sense of effective contribution to the organization, and therefore the availability of quality work style at a high level is necessary to support the productivity of employees and the organization by achieving the best balance between goals Organizational and employees' needs so it's an opportunity for continuous growth, and thus the participation of workers in planning and developing their career paths by choosing the path that guarantees their growth on a personal and organizational level, which gives them stronger opportunities in their field of specialization and interests, in order to benefit The birth of new knowledge and skills.

Managers should develop strategic plans through the participation of all employees, heads and subordinates in decision-making, by predicting in dealing with expected and unexpected situations by adapting to and exploiting them, especially with regard to customers and competitors, and perhaps the most important thing managers must adopt is the quadruple analysis process or Analysis (SWOT) or (IE Matrix), as this analysis includes accurate identification and monitoring of the strengths and weaknesses in the internal environment of the organization that constitute its human and material resources, and the identification of opportunities and threats that pose a clear danger to the work of the organization, and also Optimizing the information technology because it is considered one of the most important resources supporting organizational agility, to provide it with opportunities to identify the most important changes and developments in the shortest possible time to make decisions, this is what enables them to respond quickly to changes and take appropriate actions at the right time, the benefit of information technology has a role in achieving Effective communication between all administrative levels and different departments, which allows the exchange of information and experiences between them, which ensures the easy flow of data and information that individuals need in their work and achieves more flexibility and harmony between the Various career levels.

\section{References}

Adel, A., \& Pishdar, M. (2011). Identification and index measurement of organizational agility. Journal of management research, 4(11), 5-20.

Aitken, J., Christopher, M., \& Towill, D. (2002). Understanding, implementing and exploiting agility and leanness. International journal of Logistics, 5(1) 59-74

Albrecht K. (2003). The power of minds at work: Organizational intelligence in action. Amacom Books. 
INTERNATIONAL JOURNAL OF ACADEMIC RESEARCH IN BUSINESS AND SOCIAL SCIENCES

Vol. 10, No. 2, Feb, 2020, E-ISSN: 2222-6990 @ 2020 HRMARS

Albrecht, K. (2002). Organizational intelligence profile: Preliminary assessment questionnaire. Retrieved from Karl Albrecht International: https://www. karlalbrecht. com/downloads/Albrecht.

Argyris, C., and Schön, D. (1978). Organizational learning: A theory of perspective. San Francisco: Jossey Bass

BAGHERZADEH, M., \& AKBARI, D. A. (2010). Relationship between intelligence and organizational agility.

Bakhshian, A., Hamidi, F., \& Ezati, M. (2011). Relationship between organizational intelligence and entrepreneurship among university educational managers. J Math Comput Sci, 3(4), 413-21.

Blue, D. (2011). Helping your organization gain in learning agility. International Journal of Leadership Studies, 5(2), 301-307.

Breu, K., Hemingway, C. J., Strathern, M., \& Bridger, D. (2002). Workforce agility: the new employee strategy for the knowledge economy. Journal of Information technology, 17(1), 21-31.

Cakir, R., \& Ada, S. (2008). Can the organizational intelligence be developed in schools by in-service training? World Applied Sciences Journal, 4(1), 24-30.

Chaman, K., Hesam, S., \& Yazdanpanah, A. (2016). Relationship between organizational intelligence and hospitals agility of shiraz university of medical sciences.

Cronin B., \& Davenport, E. (1991). Elements of information management. Scarecrow Pr.

Daft, R. L., \& Weick, K. E. (1984). Toward a model of organizations as interpretation systems. Academy of management review, 9(2), 284-295.

Daraei, M. R., Ahmadi, S. A. A., \& Faraji, S. (2015). The study of relationship between meritocracy in appointment of personnel and motivation for their career promotion and achievement. International Journal of Research in Organizational Behavior and Human Resource Management, 3(1), 73-86.

Dolat Modeli, M. (2008). Strategies for achieving agility in organizations. Web magazine, 72, 67-83.

Dutton, J. E. (1988). Perspectives on strategic issue processing: Insights from a case study. Advances in strategic management, 5, 223-244.

Dutton, J. E., \& Ottensmeyer, E. (1987). Strategic issue management systems: Forms, functions, and contexts. Academy of Management Review, 12(2), 355-365.

Dutton, J., \& Duncan, R. (1987). Strategic issue diagnosis and creation of momentum for change. Strategic Management Journal, 8(3), 279-295.

Eisenhardt, K. M., \& Martin, J. A. (2000). Dynamic capabilities: what are they? Strategic management journal, 21(10-11), 1105-1121.

El Sawy, O. A. (1985). Personal information systems for strategic scanning in turbulent environments can the CEO go on-line?. MiS Quarterly, 53-60.

Erande, A. S., \& Verma, A. K. (2008). Measuring agility of organizations-a comprehensive agility measurement tool (CAMT). International journal of applied management and technology, 6(3).

Erande, A. S., \& Verma, A. K. (2008). Measuring agility of organizations-a comprehensive agility measurement tool (CAMT). International journal of applied management and technology, 6(3).

Florin, L. E. O. N., \& Atanasiu, G. M. (2008). Integrating artificial intelligence into organizational intelligence. Management \& Marketing, 3(2).

Glynn, M. A. (1996). Innovative genius: A framework for relating individual and organizational intelligences to innovation. Academy of management review, 21(4), 1081-1111.

Gunasekaran, A. (1999). Agile manufacturing: a framework for research and development. International journal of production economics, 62(1-2), 87-105. 
INTERNATIONAL JOURNAL OF ACADEMIC RESEARCH IN BUSINESS AND SOCIAL SCIENCES

Vol. 10, No. 2, Feb, 2020, E-ISSN: 2222-6990 @ 2020 HRMARS

Gupta, J. N., \& Sharma, S. K. (Eds.). (2004). Creating knowledge-based organizations. Igi Global.

Halal, W. E. (1997). Organizational intelligence: What is it, and how can managers use it. Recuerado de http://www. strategy-business. com/article/12644.

Houghton, R., El Sawy, O. A., Gray, P., Donegan, C., \& Joshi, A. (2008). Vigilant information systems for managing enterprises in dynamic supply chains: Real-time dashboards at Western Digital. MIS Quarterly Executive, 3(1), 4.

Harraf, A., Wanasika, I., Tate, K., \& Talbott, K. (2015). Organizational agility. Journal of Applied Business Research (JABR), 31(2), 675-686.

Jaafarnejad, A., \& Shahabi, B. (2007). Organization Agility and agile Production. MehrbanNashr Publication.

Janssen, L. M. A. W. (2010). Organizational agility in an institutional context. Supervisors: drs. MCP Nijssen \& prof. dr. J. Paauwe.

Khodadadi, M. R., Kashef, M., Seyed Ameri, M., \& Aalami Kashki, M. (2013). The relationship between the components of organizational intelligence and organizational culture in the general department of exercise of east Azerbayjan. Exercise Management, 5(3), 175-189.

Kord, B., Ghasemi, M., \& Khazaei Amin, A. (2013). Measuring the organizational intelligence of the experts and managers of the cement factory in Sistan. European Online Journal of Natural and Social Sciences: Proceedings, 2(3 (s)), pp-959.

Lefter, V., Prejmerean, M., \& Vasilache, S. (2008). The dimensions of organizational intelligence in Romanian companies-a human capital perspective. Theoretical and Applied Economics, 10(10), 39.

Liebowitz, J. (2019). Building organizational intelligence: A knowledge management primer. CRC press.

Mahmoudi, H. S., \& Asgari, M. H. (2013). Investigation of Relationship between Organizational Intelligence and Agility of High School Administrators in Mazandaran Province, Iran. International Research Journal of Applied and Basic Sciences, 5(7), 905-911.

Mansouri, A. M., Rahimi, G., Bohluli, N., \& Irani, F. N. (2019). IDENTIFYING PSYCHOLOGICAL TRAITS OF MIDDLE MANAGERS IN THE OIL INDUSTRY.

March, J. G. (1999). Exploration and exploitation in organizational learning. The pursuit of organizational intelligence.

Matsuda, T. (1988). OR/MS, its interaction with and benefit from Japanese organizational intelligence. Omega, 16(3), 233-241.

McCann, J., Selsky, J., \& Lee, J. (2009). Building agility, resilience and performance in turbulent environments. People \& Strategy, 32(3), 44-51.

McCarthy, I. P., Lawrence, T. B., Wixted, B., \& Gordon, B. R. (2010). A multidimensional conceptualization of environmental velocity. Academy of management review, 35(4), 604-626.

McMaster, M. D. (1996). The intelligence advantage: Organizing for complexity. Boston: ButterworthHeinemann.

Park, Y. (2011). The Dynamics of Opportunity and Threat Management in Turbulent Environments: The Role Information Technologies. Doctor Dissertation.

Prater, E., Biehl, M., \& Smith, M. A. (2001). International supply chain agility-Tradeoffs between flexibility and uncertainty. International journal of operations \& production management.

Prater, E., Biehl, M., \& Smith, M. A. (2001). International supply chain agility-Tradeoffs between flexibility and uncertainty. International journal of operations \& production management. 
INTERNATIONAL JOURNAL OF ACADEMIC RESEARCH IN BUSINESS AND SOCIAL SCIENCES

Vol. 10, No. 2, Feb, 2020, E-ISSN: 2222-6990 @ 2020 HRMARS

Quinn, J. B. (1992). Intelligent Enterprise: A Knowledge and Service Based Paradigm for Industr. Simon and Schuster.

Ramesh, G., \& Devadasan, S. R. (2007). Literature review on the agile manufacturing criteria. Journal of Manufacturing Technology Management.

Rasouli, E., Soodi, S., \& Jafarzadeh, Z. (2016). Studying the relationship between organizational intelligence and organizational agility of employees of Payame Noor University of Sari. International Journal of Organizational Leadership, 5, 426-432.

Ribeiro, F. L., \& Fernandes, M. T. (2010). Exploring agile methods in construction small and medium enterprises: a case study. Journal of Enterprise Information Management.

Ruhan, A., lijima, J., \& Sho, H. (2009). A study on relationship between organizational intelligence quotient and firm performance-A comparison study between Japan and China. Tokyo Institute of Technology.

Sattari, M. (2007). The relationship between knowledge maangement in learining organization and emotional intelligence in Zoube Ahan Efahana Company. First Conferenceon Knowledge Management, Tehran, Iran.

Seyyed Ameri, M. H. (2009). Determining the relationship between conflict management strategies (interpersonal) and spirit and job satisfaction of sports coaches of department of Physical Education of Urmia. Journal of Research in Sports Sciences, 22, 67-80.

Simic, I. (2005). Organizational learning as a component of organizational intelligence.

Smircich, L., \& Stubbart, C. (1985). Strategic management in an enacted world. Academy of management Review, 10(4), 724-736.

Sohrabi, R., Asari, M., \& Hozoori, M. J. (2014). Relationship between Workforce Agility and Organizational Intelligence (Case Study: The Companies of" Iran High Council of Informatics"). Asian Social Science, 10(4), 279.

Stratton, R., \& Warburton, R. D. (2003). The strategic integration of agile and lean supply. International Journal of production economics, 85(2), 183-198.

Thannhuber, M. J. (2005). The Intelligent Enterprise: The Application of the Derived Theoretical Framework to the Domain of Business and Engineering Management. The Intelligent Enterprise: Theoretical Concepts and Practical Implications, 67-85.

Thomas, J. B., Clark, S. M., \& Gioia, D. A. (1993). Strategic sensemaking and organizational performance: Linkages among scanning, interpretation, action, and outcomes. Academy of Management journal, 36(2), 239-270.

Travica, B. (2015). Modeling organizational intelligence: Nothing googles like Google. Online Journal of Applied Knowledge Management, 3(2), 1-18.

Travica, B. (2015). Modeling organizational intelligence: Nothing googles like Google. Online Journal of Applied Knowledge Management, 3(2), 1-18.

Van Hoek, R. I., Harrison, A., \& Christopher, M. (2001). Measuring agile capabilities in the supply chain. International Journal of Operations \& Production Management.

Wassermann, O. (2001). The intelligent organization: Winning the global competition with the supply chain idea. Springer Science \& Business Media.

Wilensky, H. L. (1967). Organizational intelligence: Knowledge and policy in government and industry (Vol. 19). Quid Pro Books.

Wassermann, O. (2001). The intelligent organization: Winning the global competition with the supply chain idea. Springer Science \& Business Media. 
INTERNATIONAL JOURNAL OF ACADEMIC RESEARCH IN BUSINESS AND SOCIAL SCIENCES Vol. 10, No. 2, Feb, 2020, E-ISSN: 2222-6990 @ 2020 HRMARS

Yusuf, Y. Y., Sarhadi, M., \& Gunasekaran, A. (1999). Agile manufacturing: The drivers, concepts and attributes. International Journal of production economics, 62(1-2), 33-43. 